\title{
ANTI-INFLAMMATORY, ANTINOCICEPTIVE AND ANTIOXIDANT ACTIVITIES OF THE HYDROMETHANOLIC FRACTION FROM ANNONA NUTANS LEAVES
}

\author{
ATIVIDADE ANTI-INFLAMATÓRIA, ANTINOCICEPTIVA E ANTIOXIDANTE DA \\ FRAÇÃO HIDROMETANÓLICA DAS FOLHAS DE ANNONA NUTANS
}

\begin{abstract}
Nathalia L. SILVA ${ }^{1}$; Aline A. SALDANHA ${ }^{2}$; Denise B. SILVA ${ }^{3}$; Carlos A. CAROLLO³; Ângela L. B. SARTORI ${ }^{4}$; Adriana C. SOARES ${ }^{5}$;oão M. de SIQUEIRA ${ }^{6}$

1. Doutoranda, Laboratório de Farmacognosia/Química de Produtos Naturais, Campus Centro-Oeste, Universidade Federal de São João Del Rei, Divinópolis, MG, Brazil; 2. Doutoranda, Laboratório de Farmacologia da Dor e Inflamação, Campus Centro-Oeste,

Universidade Federal de São João Del Rei, Divinópolis, MG, Brazil; 3. Doutor, Laboratório de Produtos Naturais e Espectrometria de Massas, Universidade Federal de Mato Grosso do Sul, Campo Grande, MS, Brazil; 4. Doutor, Centro de Ciências Biológicas e da Saúde, Universidade Federal de Mato Grosso do Sul, Campo Grande, MS, Brazil; 5. Doutor, Laboratório de Farmacologia da Dor e Inflamação, Campus Centro-Oeste, Universidade Federal de São João Del Rei, Divinópolis, MG, Brazil; 6. Doutor, Laboratório de

Farmacognosia/Química de Produtos Naturais, Campus Centro-Oeste, Universidade Federal de São João Del Rei, Divinópolis, MG, Brazil.jmaximo@ufsj.edu.br
\end{abstract}

\begin{abstract}
Annona nutans (Annonaceae) is a plant species found in Bolivia, Paraguay, Argentina, and the Brazilian Cerrado, specifically in the states of Mato Grosso and Mato Grosso do Sul (Brazil). Its common names are Araticû-Mi and Aratic $\hat{u}-\tilde{N} u$. The research contributions regarding the chemical composition and biological activities of extracts from $A$. nutans are rare, with only four articles being found in the literature. Therefore, the present study evaluated the anti-inflammatory and antinociceptive activities of the hydromethanolic fraction (FHMeOH) using carrageenan-induced paw edema and hot-plate tests. In addition, the antioxidant activity was evaluated by DPPH radical scavenging, total phenolic, flavonoid and tannin content assays and quantification of the major metabolites by LC-MS were performed. Oral treatment with the $\mathrm{FHMeOH}$ (at a dose of $300 \mathrm{mg} \cdot \mathrm{kg}^{-1}$ ) significantly reduced paw edema $2 \mathrm{~h}$ and $4 \mathrm{~h}$ after the inflammatory stimulus. The intraperitoneal (i.p.) treatment with the $\mathrm{FHMeOH}\left(50\right.$ and $\left.100 \mathrm{mg} \cdot \mathrm{kg}^{-1}\right)$ proved to be most effective, and the inhibition of acute inflammation was still visible $6 \mathrm{~h}$ after carrageenan injection. At doses of 50 and $100 \mathrm{mg} \cdot \mathrm{kg}^{-1}$ (i.p.), FHMeOH exhibits central antinociceptive effects by increasing the latency of the reaction in the hot-plate model. The $\mathrm{FHMeOH}$ showed antioxidant potential, and the metabolites quercetin-3$O$-galactoside, quercetin-3- $O$-glucoside, isorhamnetin-3- $O$-galactoside, quercetin-3- $O$ - $\beta$-D-apiofuranosyl$(1 \rightarrow 2)$-galactopyranoside, and chlorogenic acid were identified and quantified by LC-MS. Our results indicate, for the first time, that $\mathrm{FHMeOH}$ has anti-inflammatory, antinociceptive and antioxidant potential, and it is a promising source of studies for new herbal medicines
\end{abstract}

KEYWORDS: Annona nutans. Flavonoids. Anti-inflammatory. DPPH. Antinociceptive. HPLC quantification.

\section{INTRODUCTION}

Annona is among the 27 most important genera of the Annonaceae family. This genus, containing approximately 162 species distributed among the tropics, is represented mainly in South and Central America, with 110 native tropical species in the Americas and Africa (CHATROU et al., 2012; COUVREUR et al., 2011). Initially, plants belonging the Annonaceae family were believed to predominantly contain alkaloids (LEBOEUF et al., 1982); however, a great diversity of chemical constituents was recently acknowledged. Studies of species belonging to the Annonaceae family intensified following the isolation of a chemical group known as "annonaceous acetogenins", which presented a wide variety of biological activities such as cytotoxic, antitumor, pesticidal, and antimicrobial (BERMEJO, 2005; CAVÉ et al., 1997). For many years, the interest in Annona species, and other genera in the Annonaceae family, was a result of the presence of acetogenins, which showed promising pharmacological activities (BERMEJO, 2005). However, epidemiological data from the island of Guadalupe (Caribbean) have associated the consumption of Annona species (A. muricata, A. reticulata, and $A$. squamosa) with the development of atypical parkinsonism, suggesting that acetogenins and quinoline alkaloid derivatives are directly related to its etiology, because the 
acetogenin annonacin was shown to cause neurodegeneration in rats (CAPARROSLEFEBVRE; STEELE, 2005). Apart from acetogenins, plants belonging to the Annonaceae family possess a wide variety of metabolites that are responsible for important pharmacological activities, such as anti-inflammatory, antinociceptive, and antioxidant (BENITES et al., 2015; FORMAGIO et al., 2013a, 2013b).

Annona nutans (or Annona spinescens var. nutans) is a plant species found in Bolivia, Paraguay, Argentina, and the Brazilian Cerrado, specifically in the states of Mato Grosso and Mato Grosso do Sul (Brazil). Its more common names are aratico, chirimoya del campo, and sinini de la pampa; and those in the Guarani language are Aratic $\hat{u}-M i$ and Araticu- $\tilde{N} u$ (CORRÊA, 1926; TROPICOS.ORG, 2017). The research contributions regarding the chemical composition and biological activities of the extracts from $A$. nutans are rare, with only four articles found in the literature (GLEYE et al., 2000, 1998; GONÇALVES et al., 2014; SILVA et al., 2015). The acetogenins were found in A. nutans roots (GLEYE et al., 2000, 1998), with studies in the literature showing the absence of acetogenins in the leaves (SILVA et al., 2015; SILVA, 2013). Thus, the present study identified and quantified some metabolites by LC-MS and quantitated the total phenolic, tannin, and flavonoid content, in addition to assessing the antioxidant potential as DPPH radical scavenging ability from the hydromethanolic fraction (FHMeOH) of $A$. nutans. Moreover, the anti-inflammatory and antinociceptive efficacy of the $\mathrm{FHMeOH}$ was evaluated in vivo.

\section{MATERIAL AND METHODS}

\section{Plant material}

The leaves of A. nutans were collected in Porto Murtinho, the state of Mato Grosso do Sul, Brazil. The plant was previously identified by Renato de Mello-Silva, and a voucher specimen was deposited at the CGMS Herbarium (MS, Brazil) under number 27648 . The present study obtained a Certificate of Registration from the National System for the Management of Genetic Heritage and Associated Traditional Knowledge (A90D499).

\section{Preparation of fractions}

Dried and powdered leaves $(160 \mathrm{~g})$ were percolated with methanol:water $(9: 1)(5.0 \mathrm{~L})$ for 72 $\mathrm{h}$ at room temperature, yielding $32 \mathrm{~g}$ hydromethanolic extract. $28 \mathrm{~g}$ was dissolved in methanol:water $(9: 1) \quad(500 \mathrm{~mL})$, followed by sequential partitioning with n-hexane, chloroform, and ethyl acetate $(200 \mathrm{~mL}, 5 \mathrm{x}$ of each solvent). The final hydromethanolic fraction $(\mathrm{FHMeOH})$ was dried under a vacuum in a rotatory evaporator at 45 ${ }^{\circ} \mathrm{C}$, and subsequently lyophilized, yielding $21 \mathrm{~g}$. For the determination of total phenolic, tannin, and flavonoid contents, a stock solution in ethanol:water (1:1) was initially prepared from the $\mathrm{FHMeOH}$ solution at a concentration of $5 \mathrm{mg} \cdot \mathrm{mL}^{-1}$, and successive dilutions at concentrations of 5.0; 2.5; $1.25 ; 0.625 ; 0.3125 \mathrm{mg} . \mathrm{mL}^{-1}$ were prepared.

\section{Determination of the total phenolic content}

The total phenolic content was determined by spectrophotometric quantitation using the FolinCiocauteu reagent in 96-well microplates, as described previously (ZHANG et al., 2006).

Briefly, a $20 \mu \mathrm{L}$ sample (prepared as previously described) and $100 \mu \mathrm{L}$ Folin-Ciocauteu reagent (Imbralab®) were added to each well, shaken, and incubated for $5 \mathrm{~min}$. Subsequently, 80 $\mu \mathrm{L} 7.5 \% \mathrm{Na}_{2} \mathrm{CO}_{3}$ (Alphatec $\AA$ ) solution was added.

A calibration curve was generated using gallic acid (Cromato Produtos Químicos Ltda ${ }^{\circledR}$ ) at the standard at concentrations of $1 ; 0.5 ; 0.25 ; 0.125$; 0.0625 ; and $0.0312 \mathrm{mg} . \mathrm{mL}^{-1}$. For the reagent blank, $20 \mu \mathrm{L}$ methanol, $100 \mu \mathrm{L}$ Folin-Ciocauteu reagent, and $80 \mu \mathrm{L} \mathrm{7.5 \%} \mathrm{Na}_{2} \mathrm{CO}_{3}$ were used. The plates were incubated in the dark at room temperature for $2 \mathrm{~h}$. Readings were performed using a microplate spectrophotometer (SpectraMax®Plus384, Molecular Devices, Sunnyvale, CA, USA, Gen5 software) at $\lambda=750 \mathrm{~nm}$. For the instrument blank, $20 \mu \mathrm{L} \mathrm{CH} \mathrm{CH}_{3} \mathrm{OH}: \mathrm{H}_{2} \mathrm{O}(1: 1)$ and $180 \mu \mathrm{L}$ distilled water were used. The total phenolic content (TPC) was determined by interpolation of the absorbance of the samples against the calibration curve obtained for the standard and are expressed as $\mu \mathrm{g}$ of gallic acid equivalents.mg ${ }^{-1}$ for respective fractions. All analyses were performed in triplicate.

\section{Determination of the total tannin content}

Sample solutions were prepared at the same concentrations as described for the total phenolic quantitation; however, prior to the addition of FolinCiocauteu reagent, 0.01 g. $\mathrm{mL}^{-1}$ hide powder (SigmaAldrich) was added, and the solution was shaken for $60 \mathrm{~min}$ on an orbital shaker. The filtrates $(20 \mu \mathrm{L})$ were added to each well of a 96-well plate with 20 $\mu \mathrm{L}$ methanol:water (1:1) and $100 \mu \mathrm{L}$ FolinCiocauteu reagent, shaken, and incubated for $5 \mathrm{~min}$. Subsequently, $80 \mu \mathrm{L}$ of $7.5 \% \mathrm{Na}_{2} \mathrm{CO}_{3}$ solution was added, and the plates were incubated in the dark at room temperature for $2 \mathrm{~h}$. Readings were performed using a microplate spectrophotometer at $\lambda=750 \mathrm{~nm}$. 
For the instrument blank, $20 \mu \mathrm{L}$ of methanol:water (1:1) and $180 \mu$ Lof distilled water were used.

The total tannin content (TTC) was determined from the standard curve by subtracting the calculated content of the sample solution for non-adsorbed polyphenols from the calculated TPC content (sample solution for total polyphenols). The expression is shown below. The results are expressed as $\mu \mathrm{g} \cdot \mathrm{mL}^{-1}$ of sample. All analyses were performed in triplicate.

TTC $=$ content of the sample solution for total polyphenols - content of the sample solution for non-adsorbed polyphenols in hide powder (BRASIL, 2010a; VERZA et al., 2007).

\section{Determination of the total flavonoid content}

The total flavonoid content (TFC), equivalent to quercetin, present in the fractions was determined using a previously described method (BANOV et al., 2006; BRASIL, 2010b), and expressed as $\mu$ g quercetin . $\mathrm{mg}^{-1}$ fraction.

For the calibration curve, quercetin (SigmaAldrich) was used as the standard reference flavonoid, of which a stock solution of $0.01 \mu \mathrm{g} \cdot \mathrm{mL}^{-1}$ was prepared. From this stock, dilutions were prepared at concentrations of $20,10,5,4,3,2,1$, $0.75,0.5$ and $0.3 \mu \mathrm{g} . \mathrm{mL}^{-1}$, to which $500 \mu \mathrm{L} 5 \%$ (w/v) $\mathrm{AlCl}_{3}$ solution was added. Following a 30-min incubation, the absorbance was read at $425 \mathrm{~nm}$ using a UV-Vis spectrophotometer (QUIMIS $®$ ) and the calibration curve was constructed.

To $100 \mu \mathrm{L} \quad 50 \%$ methanol, $100 \mu \mathrm{L}$ $\mathrm{FHMeOH}$ and $500 \mu \mathrm{L} 5 \%(\mathrm{w} / \mathrm{v}), \mathrm{AlCl}_{3}$ solution was added. Following a 30-min incubation, the absorbance was read at $425 \mathrm{~nm}$ using a UV-Vis spectrophotometer (QUIMIS ${ }^{\circledR}$ ). All analyses were performed in triplicate.

\section{Determination of the DPPH radical-scavenging capacity}

The radical-scavenging capacity of $\mathrm{FHMeOH}$ was determined according to the method described by Burda and Oleszek (2001) (BURDA et al., 2001). BHT (2,6-di-tert-butyl-4-methylphenol) was used as the reference compound. FHMeOH was prepared in triplicate for each concentration $(1,10$, 100,250 , and $\left.500 \mu \mathrm{g} \cdot \mathrm{mL}^{-1}\right)$. Each sample $(75 \mu \mathrm{L})$ was added to three wells of a 96-well plate containing $150 \mu \mathrm{L} 0.002 \%$ (w/v) DPPH-methanol solution, shaken vigorously, and incubated in the dark for $30 \mathrm{~min}$. The control was prepared as above without any extract or BHT. The absorbance was measured at $\lambda=517 \mathrm{~nm}$ using a UV-Vis spectrophotometer (Biotek Power Wave XS2/US, U.S.A) and methanol was used for baseline correction. The radical-scavenging activity is expressed as the inhibition percentage and was calculated as:

$$
\left[1-\left(\mathrm{Abs}_{\text {control }}-\mathrm{Abs}_{\text {sample }}\right)\right] \times 100
$$

where $\mathrm{Abs}_{\text {control }}=$ absorbance of $\mathrm{DPPH}$ radicals in methanol and $\mathrm{Abs}_{\text {sample }}=$ absorbance of fraction in methanol $+\mathrm{DPPH}$. The scavenging activity is expressed as $\mu \mathrm{g} \cdot \mathrm{mL}^{-1}$. $\mathrm{IC}_{50}$ values $\left(\mu \mathrm{g} . \mathrm{mL}^{-1}\right)$ were calculated using Probit analysis (FINNEY, 1980).

\section{Identification and quantitative UFLC-DAD- ESI- QTOF-MS analysis}

The identification and quantification of phytocompounds was performed on a Shimadzu Prominence UFLC TM system, equipped with a LC20AD, coupled to a diode array detector and mass spectrometer (MicroOTOF-Q III Bruker Daltonics, Billerica, USA) with an electrospray ion source. The analyses were monitored between 210 and $800 \mathrm{~nm}$ and the mass spectrometer operated in a negative ionization mode $(\mathrm{m} / \mathrm{z}, 120-1300)$. Chromatographic analyses were performed in a Kinetex C-18 column (Phenomenex, $2.6 \mu, 150 \mathrm{x}$ $2.1 \mathrm{~mm})$. For quantification, $\mathrm{FHMeOH}$ was dissolved in methanol and water $(1: 1, \mathrm{v} / \mathrm{v})$ at a concentration of $1 \mathrm{mg} \cdot \mathrm{mL}^{-1}$. Standard solutions at a concentration of $1 \mathrm{mg} \cdot \mathrm{mL}^{-1}$ were prepared with chlorogenic acid (5-O-caffeoylquinic acid), the flavonoids quercetin-3-O-galactopyranoside, quercetin-3-O-glucopyranoside, and isorhamnetin3-O-galactopyranoside (Sigma Aldrich ${ }^{\circledR}$ ). For the analytical curve, dilutions were prepared at the concentrations from 0.0488 to $200.00 \mu \mathrm{g} \cdot \mathrm{mL}^{-1}$ $(0.0488,0.0976,0.195,0.390,0.781,1.56,3.12$, $6.25,12.50,25.00,50.00,100.00$, and 200.00 $\left.\mu \mathrm{g} . \mathrm{mL}^{-1}\right)$. For the isorhamnetin-3-Ogalactopyranoside, concentrations of 12.5, 25.0, 50.0, 100.0, and $200.0 \mu \mathrm{g} . \mathrm{mL}^{-1}$ were prepared. About $3 \mu \mathrm{L}$ of sample was injected in to the column by the auto sampler. The samples were eluted through the column with a gradient mobile phase consisting of A (water $0.1 \%$ (v/v) formic acid) and B (acetonitrile: formic acid $0.1 \%(\mathrm{v} / \mathrm{v}))$. The gradient elution was programmed as follows: $0-2$ $\min \mathrm{B}(3 \%) ; 2-25 \min \mathrm{B}(25 \%) ; 25-26 \min \mathrm{B}$ (80\%); 26-28 min B (80\%); 28-29 min B (3\%); and 29-35 min B (3\%). The analyses were carried out in triplicate at a flow rate of $0.3 \mathrm{~mL} \cdot \mathrm{min}^{-1}$, at a temperature of $50{ }^{\circ} \mathrm{C}$, with the detector set at $\lambda=340$ $\mathrm{nm}$. Calibration curves were plotted showing a linear relationship between concentrations versus peak areas for all reference compounds. The 
attribution of the chromatographic peak was based on the retention times and confirmed by the injection of standards. The concentration of each peak was calculated from the experimental peak areas by analytical interpolation in a standard calibration line. Peak areas were calculated at 340 $\mathrm{nm}$. The limit of detection (LOD) was determined as a signal-to-noise ratio of $3: 1$ and the limit of quantification (LOQ) was determined as a signal-tonoise ratio of 10:1 (GARCÍA-SALAS et al., 2015). The precision was calculated by relative standard deviation (\%RSD), and the selectivity was evaluated by comparing the chromatograms of the individual reference standards and the degree of interference between the peaks when injected simultaneously; the degree of purity of these peaks was also investigated (BRITO, 2014; RIBANI et al., 2004).

\section{In vivo assays}

\section{Chemicals}

Indomethacin (Ind) and carrageenan $\lambda$ type IV were purchased from Sigma-Aldrich Inc. (St. Louis, MO, USA). Fentanyl citrate (Fent) was purchased from Cristália (SP, Brazil). DMSO 2\% in physiological saline was used as the control, and $\mathrm{FHMeOH}$ was prepared in this vehicle for oral or intraperitoneal treatments to mice.

\section{Animals}

Adult male Swiss mice $(28-30$ g) were obtained from the Bioterium of Universidade Federal de São João del-Rei, Brazil, and were housed in temperature-controlled rooms $\left(22-25^{\circ} \mathrm{C}\right)$, under a $12-12 \mathrm{~h}$ light-dark cycle, with access to food and water ad libitum. The mice were acclimated for one week prior to the experiment. Twelve hours prior to the beginning of oral treatments, the mice were fasted and received only water ad libitum. For the intraperitoneal experiment, the food and water were retained. The number of mice and the intensity of noxious stimuli used were the minimum necessary to demonstrate consistent effects of the drug treatments. All procedures were carried out in accordance with the guidelines set forth by the Brazilian National Council for the Control of Animal Experimentation and International Association for the Study of Pain and were approved by the Ethics Committee in Animal Experimentation of the Federal University of São João Del-Rei, Brazil (CEUA/UFSJ, protocol 034/2015).

\section{Assessment of the anti-inflammatory activity}

The anti-inflammatory activity was assayed using the carrageenan-induced paw edema model (LEVY, 1969). Mice were randomly divided into five groups $(n=6)$, and orally (p.o.) received vehicle (10 mL. $\mathrm{kg}^{-1}$, control group), FHMeOH (at doses of 30,100 , and $\left.300 \mathrm{mg} \cdot \mathrm{kg}^{-1}\right)$, or indomethacin $(10$ mg. $\mathrm{kg}^{-1}$ ). Moreover, FHMeOH, at doses of 25, 50 and $100 \mathrm{mg} \cdot \mathrm{kg}^{-1}$, were intraperitoneally (i.p.) administered. Following 30 (i.p.) or 60 (p.o.) min following treatments, carrageenan $(400 \mu \mathrm{g}, 30 \mu \mathrm{L})$ was injected into the plantar side of the left hind paw. Paw volume was measured using a plethysmometer (Insight ${ }^{\circledR}$, Brazil) prior to treatment (basal value) and at 1, 2, 4, and $6 \mathrm{~h}$ after the injection of the inflammatory stimulus. The volume of edema was calculated by the difference between the prior basal paw volume and the one after carrageenan injection.

\section{Evaluation of the antinociceptive activity}

Mice were tested on a hot-plate $\left(\right.$ Insight $^{\circledR}$, Brazil) kept at a constant temperature of $55 \pm 0.50$ ${ }^{\circ} \mathrm{C}$ for $24 \mathrm{~h}$ before the assay, and animals that remained on the apparatus for less than $15 \mathrm{~s}$ were selected. Thus, the selected animals were randomly divided into five groups $(\mathrm{n}=7)$ and received (i.p.) vehicle (10 mL. $\mathrm{kg}^{-1}$, control group), FHMeOH (at doses of 25, 50, and $100 \mathrm{mg} . \mathrm{kg}^{-1}$ ), and Fentanyl (Fent $200 \mu \mathrm{g} \cdot \mathrm{kg}^{-1}$ ). Reaction times were recorded when the mice licked their paws or jumped at intervals of $30 \mathrm{~min}$ up to $120 \mathrm{~min}$ after treatments. A cut-off of 30s was chosen to avoid tissue lesions (MUHAMMAD; SAEED; H., 2012).

\section{Statistical analysis}

Microsoft Excel 2010 (Microsoft Corporation) was used for the quantitation of the total phenolic, tannin, and flavonoid content. In the evaluation of the anti-inflammatory and antinociceptive activities, results are expressed as the mean \pm SEM. The statistical significance between groups was assessed using one-way analysis of variance (ANOVA) followed by the Bonferroni multiple comparison post-hoc test. All calculations for anti-inflammatory, antinociceptive activities and DPPH radical-scavenging capacity were performed using GraphPad Prism ${ }^{\mathrm{TM}}$ version 5.01 (GraphPad® Software Inc., San Diego, CA). A level of significance $(p<0.05)$ was considered for each experiment. 


\section{RESULTS}

\section{Total phenolic, tannin and flavonoid content}

The total phenolic, tannin, and flavonoid content of the $\mathrm{FHMeOH}$ extract from A. nutans was calculated based on the interpolation of the absorbance values of the samples from the calibration curve of gallic acid (TPC and TTC), which presented the following equation of the line, $\mathrm{y}=0.2352 \mathrm{x}+0.0044, \mathrm{R}^{2}=0.9982$, and from the calibration curve of quercetin (TFC), which presented $y=0.0228 x+0.0027, R^{2}=0.9986$. The total phenolic, tannin, and flavonoid content was
$62.96 \pm 3.73 \mu \mathrm{g} \cdot \mathrm{mg}^{-1}, 31.14 \pm 3.11 \mu \mathrm{g} \cdot \mathrm{mg}^{-1}$, and $18.07 \pm 0.10 \mu \mathrm{g} . \mathrm{mg}^{-1}$, respectively.

\section{Determination of DPPH radical-scavenging capacity}

The DPPH radical-scavenging activity of the $\mathrm{FHMeOH}$ extract from $A$. nutans is presented in Figure 1. FHMeOH showed a dose-dependent inhibitory effect with an $\mathrm{IC}_{50}$ of $4.89 \mu \mathrm{g} \cdot \mathrm{mL}^{-1}$, which was comparable to that of the commercial antioxidant, BHT $\left(\mathrm{IC}_{50}=16.36 \pm 3,63 \mu \mathrm{g} \cdot \mathrm{mL}^{-1}\right)$. The $\mathrm{FHMeOH}$ at doses of $1,10,100$ and 250 $\mu \mathrm{g} . \mathrm{mL}^{-1}$ presented a scavenging effect on the DPPH radical that was statistically significant compared to the BHT standard.

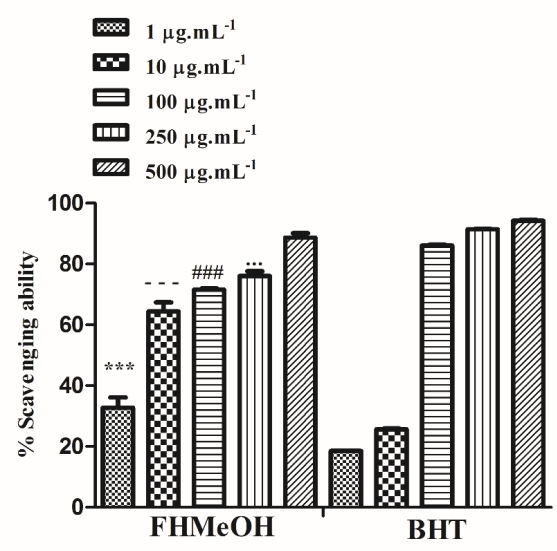

Figure 1. The DPPH radical-scavenging ability of the hydromethanolic fraction $(\mathrm{FHMeOH})$ and 2,6-di-tertbutyl-4-methylphenol (BHT) at five different concentrations $\left(\mu \mathrm{g} \cdot \mathrm{mL}^{-1}\right) . p<0.001$ as compared with BHT.

\section{Identification and quantitative UFLC-DAD- ESI- QTOF-MS analysis}

For the analytical curve and linearity, the regression equations were $\mathrm{y}=12222 \mathrm{x}-18557\left(\mathrm{R}^{2}=\right.$ $0.9992)$ for chlorogenic acid; $y=10087 x-13571$ $\left(\mathrm{R}^{2}=0.9992\right)$ for quercetin-3-O-galactopyranoside; $\mathrm{y}=9454.4 \mathrm{x}-13865\left(\mathrm{R}^{2}=0.9991\right)$ for quercetin-3$O$-glucoside; and y $=8597.5 \mathrm{x}+12942\left(\mathrm{R}^{2}=\right.$ $0.9995)$ for isorhamnetin-3-O-galactopyranoside.

The limit of detection (LOD) for all flavonoids was $4.88 \times 10^{-2} \mu \mathrm{g} \cdot \mathrm{mL}^{-1}$ and chlorogenic acid was $9.77 \times 10^{-2} \mu \mathrm{g} \cdot \mathrm{mL}^{-1}$. The limit of quantification (LOQ) was $1.95 \times 10^{-1} \mu \mathrm{g} \cdot \mathrm{mL}^{-1}$ for flavonoids and $3.91 \times 10^{-1} \mu \mathrm{g} . \mathrm{mL}^{-1}$ for chlorogenic acid. Relative standard deviations (\%RSD) were in the range of $0.11 \%$ to $3.49 \%$ and they were calculated as a mean of the three replications.

The estimated concentration of metabolites was calculated in $\mu \mathrm{g} \cdot \mathrm{mg}^{-1}$ of $\mathrm{FHMeOH}$ measuring $3.04 \mu \mathrm{g} . \mathrm{mg}^{-1}$ of chlorogenic acid, $6.74 \mu \mathrm{g} . \mathrm{mg}^{-1}$ of quercetin-3-O-galactopyranoside, $3.62 \mu \mathrm{g} . \mathrm{mg}^{-1}$ of quercetin-3-O-glucopyranoside, $2.12 \mu \mathrm{g} \cdot \mathrm{mg}^{-1}$ of isorhamnetin-3-O-galactopyranoside, and 4.86 $\mu \mathrm{g} . \mathrm{mg}^{-1}$ of quercetin-3-O- $\beta$-D-apiofuranosyl-( $\left.1 \rightarrow 2\right)$ galactopyranoside. Since the metabolite, quercetin$3-O-\beta$-D-apiofuranosyl-( $(1 \rightarrow 2)$-galactopyranoside, had no reference standard, its content was calculated based on the analytical curve of quercetin-3-O- $\beta$ galactopyranoside with a correction factor based on the corresponding molecular weight, because they have the same aglycone and thus the same chromophore group. This compound (quercetin-3$O$ - $\beta$-D-apiofuranosyl-( $1 \rightarrow 2)$-galactopyranoside) was identified in studies conducted in our laboratory using $\mathrm{H}^{1}$ and $\mathrm{C}^{13}$ NMR, COSY and DEPT techniques (SILVA et al., 2015; SILVA, 2013)

The $\mathrm{FHMeOH}$ was also analyzed by UFLCDAD-MS to identify its chemical constituents. The compounds were identified by the comparison of UV spectra and retention time with applied patterns and subsequent confirmation of their molecular weights and their fragmentation in $\mathrm{MS}^{2}$. The compounds identified are listed in Table 1 and illustrated on the chromatogram in Figure 2.

Twenty-three compounds could be detected and identified from $\mathrm{FHMeOH}$. Chlorogenic acids derivatives identified were 3-O-E-caffeoylquinic 
acid (3) and 4-O-E-caffeoylquinic acid (7), as well as the O-glycosylated flavonols $\mathbf{1 4 - 2 2}$ and alkaloids 4, 6, 8-11 and 23. These compounds were identified by comparing the spectral data reported for them in the literature (CLIFFORD et al., 2003; LIU et al., 2018) and data were also reported from Annona species for the alkaloids (FERRAZ et al., 2017; SHANGGUAN et al., 2018).

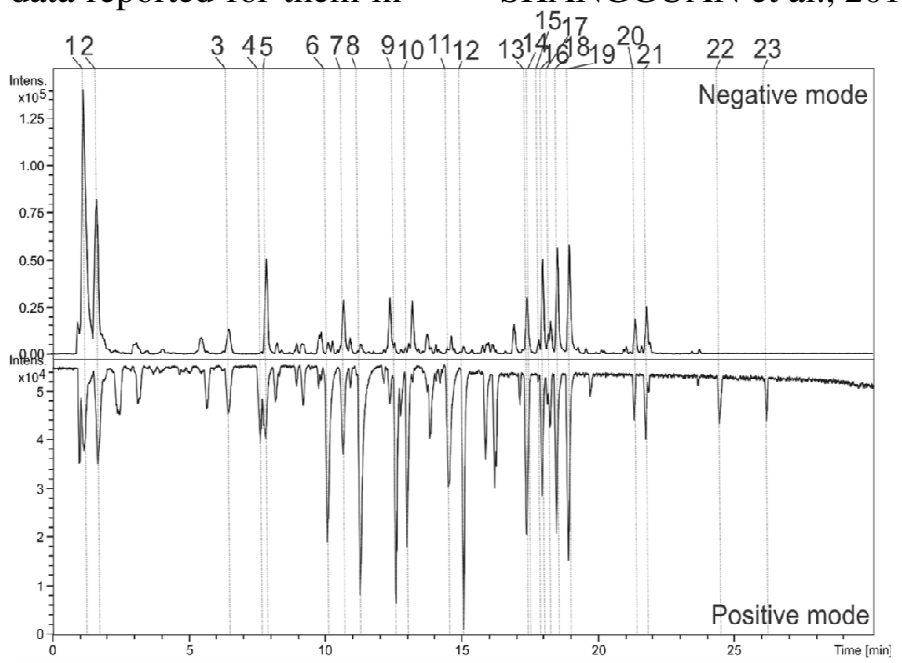

Figure 2. Base peak chromatogram obtained in negative and positive ion modes from $\mathrm{FHMeOH}$ of $A$. nutans.

Table 1. Constituents identified by UFLC-DAD-MS from FHMeOH

\begin{tabular}{|c|c|c|c|c|c|c|c|c|}
\hline \multirow[t]{2}{*}{$\overline{\text { Peak }}$} & \multirow{2}{*}{$\begin{array}{l}\text { RT } \\
(\min )\end{array}$} & \multirow{2}{*}{ Compound } & \multirow[t]{2}{*}{ MF } & \multirow{2}{*}{$\begin{array}{l}\text { UV } \\
(\mathbf{n m})\end{array}$} & \multicolumn{2}{|c|}{ Negative mode $(\mathrm{m} / \mathrm{z})$} & \multicolumn{2}{|c|}{ Positive mode $(\mathrm{m} / \mathrm{z})$} \\
\hline & & & & & MS [M-H] & MS/MS & $\begin{array}{l}\text { MS } \\
{[\mathbf{M}+\mathbf{H}]^{+}}\end{array}$ & MS/MS \\
\hline 1 & 1.2 & $O$-dihexoside & $\mathrm{C}_{12} \mathrm{H}_{22} \mathrm{O}_{11}$ & - & 341.1086 & 191 & $365.1068^{\mathrm{Na}}$ & \\
\hline 2 & 1.7 & NI & $\mathrm{C}_{11} \mathrm{H}_{22} \mathrm{O}_{8}$ & - & 279.1087 & - & 281.1252 & \\
\hline 3 & 6.4 & $\begin{array}{l}\text { 3-O-E-caffeoylquinic } \\
\text { acid }\end{array}$ & $\mathrm{C}_{16} \mathrm{H}_{17} \mathrm{O}_{9}$ & $\begin{array}{l}299, \\
323\end{array}$ & 353.0885 & 191,179 & 355.1043 & 163 \\
\hline 4 & 7.5 & $\begin{array}{l}\text { norcoclaurine- } \\
\text { hexoside }\end{array}$ & $O-\mathrm{C}_{27} \mathrm{H}_{35} \mathrm{NO}_{12}$ & - & - & - & 566.2268 & $\begin{array}{l}272,255, \\
161\end{array}$ \\
\hline 5 & 7.9 & NI & $\mathrm{C}_{19} \mathrm{H}_{28} \mathrm{O}_{11}$ & 275 & 431.1555 & - & 433.1728 & $\begin{array}{l}205,187, \\
175\end{array}$ \\
\hline 6 & 10.1 & NI & $\mathrm{C}_{18} \mathrm{H}_{19} \mathrm{NO}_{4}$ & 288 & 312.1239 & - & 314.1406 & 178,163 \\
\hline 7 & 10.7 & $\begin{array}{l}\text { 4-O-E-caffeoylquinic } \\
\text { acid }^{\text {st }}\end{array}$ & $\mathrm{C}_{16} \mathrm{H}_{18} \mathrm{O}_{9}$ & $\begin{array}{l}299 \\
325\end{array}$ & 353.0886 & 191,173 & 355.1027 & 163 \\
\hline 8 & 11.3 & $\begin{array}{l}\text { di- } O \text {-methoxyl } \\
\text { hydroxyl aporphin } \\
\text { alkaloid }\end{array}$ & $\begin{array}{l}\text { di- } \mathrm{C}_{18} \mathrm{H}_{19} \mathrm{NO}_{4} \\
\text { ne }\end{array}$ & 285 & 312.1254 & - & 314.1409 & $\begin{array}{l}298, \quad 284, \\
270,151\end{array}$ \\
\hline 9 & 12.6 & NI & $\mathrm{C}_{17} \mathrm{H}_{19} \mathrm{NO}_{3}$ & 285 & - & - & 286.1456 & $\begin{array}{l}254, \quad 237 \\
209, \quad 191, \\
175,165\end{array}$ \\
\hline 10 & 13.0 & Stepharine & $\mathrm{C}_{18} \mathrm{H}_{19} \mathrm{NO}_{3}$ & 285 & - & - & 298.1451 & $\begin{array}{ll}254, & 238, \\
223, & 161, \\
146 & \end{array}$ \\
\hline 11 & 14.5 & Magnoflorine & $\mathrm{C}_{20} \mathrm{H}_{24} \mathrm{NO}_{4}^{+}$ & 280 & - & - & $342.1712^{*}$ & $\begin{array}{ll}297, & 282, \\
265, & 237, \\
192 & \end{array}$ \\
\hline 12 & 15.1 & NI & $\mathrm{C}_{19} \mathrm{H}_{23} \mathrm{NO}_{4}$ & 283 & 328.1566 & - & 330.1708 & $\begin{array}{l}284, \quad 267, \\
192,177\end{array}$ \\
\hline 13 & 17.4 & NI & $\mathrm{C}_{19} \mathrm{H}_{32} \mathrm{O}_{8}$ & - & 387.2021 & - & 389.2180 & $\begin{array}{l}227, \quad 209 \\
191,173\end{array}$ \\
\hline 14 & 17.5 & $\begin{array}{l}\text { Quercetin- } O \text {-hexosyl- } \\
\text { deoxyhexoside }\end{array}$ & $\mathrm{C}_{27} \mathrm{H}_{30} \mathrm{O}_{16}$ & $\begin{array}{l}270 \\
350\end{array}$ & 609.1443 & $300,271,255$ & 611.1605 & 303 \\
\hline 15 & 17.8 & Quercetin- $O$-hexosyl- & $\mathrm{C}_{27} \mathrm{H}_{30} \mathrm{O}_{16}$ & 270 & 609.1453 & $300,271,255$ & 611.1623 & 303 \\
\hline
\end{tabular}


deoxyhexoside

1618.0 Quercetin-3- $O-\beta$-Dapiofuranosyl- $(1 \rightarrow 2)-$ galactopyranoside

1718.2 Quercetin- $O$-hexosyldeoxyhexoside

1818.3 Quercetin- $O$-pentosylhexoside

1918.5 Quercetin-3-O- $\beta$ galactopyranoside ${ }^{\text {st }}$

2019.0 Quercetin-3- $O-\beta$ glucopyranoside ${ }^{\text {st }}$

2121.4 Quercetin- $O$-methyl-O- $\mathrm{C}_{22} \mathrm{H}_{22} \mathrm{O}_{12}$ hexoside

2221.8 Quercetin- $O$-methyl-O- $\mathrm{C}_{22} \mathrm{H}_{22} \mathrm{O}_{12}$ hexoside

2324.5 Xylopine

$\mathrm{C}_{18} \mathrm{H}_{17} \mathrm{NO}_{3}$

$\mathrm{C}_{21} \mathrm{H}_{20} \mathrm{O}_{12}$

$\mathrm{C}_{21} \mathrm{H}_{20} \mathrm{O}_{12}$

$\mathrm{C}_{22} \mathrm{H}_{22} \mathrm{O}_{12}$
350

$265, \quad 595.1305$

350

270 , 350

265 ,

350

265 ,

352

266 ,

348

268 ,

350

265 ,

350

284

463.0872
$609.1441300,271,255,611.1630$ 179

$595.1289300,271,255,597.1485$

243,179

$300,271,255,465.1044$

243

$463.0881300,271,255,465.1044$

243,179

$477.1031314,299,285,479.1196$

$271,257,243$

$477.1027314,299,285,479.1201$

$271,257,243$

296.1288
465,303

465,303

465,303

303

303

$317, \quad 302$,

285

$317, \quad 302$,

285

$279, \quad 264$,

$249, \quad 234$,

221,206 ,

178

$553.8154^{* *} \quad 482, \quad 416$,

$359, \quad 237$,

209

RT: retention time, MF: molecular formula; NI: non-identified; ${ }^{\mathrm{Na}}:[\mathrm{M}+\mathrm{Na}]^{+} ;{ }^{*}:[\mathrm{M}]^{++}{ }^{* *}[\mathrm{M}+2 \mathrm{H}]^{+2}$; ${ }^{\text {st }}$ confirmed by the injection of authentic standard

\section{Anti-inflammatory effect of the FHMeOH}

With respect to the anti-inflammatory activity, at 2 and $4 \mathrm{~h}$ post-carrageenan injection, the p.o. administration of $300 \mathrm{mg} \cdot \mathrm{kg}^{-1} \mathrm{FHMeOH}$ promoted a significant reduction in paw edema by $48.57 \%(p<0.05)$ and $52.0 \%(p<0.05)$, respectively, as compared with the control group (Figure 3).

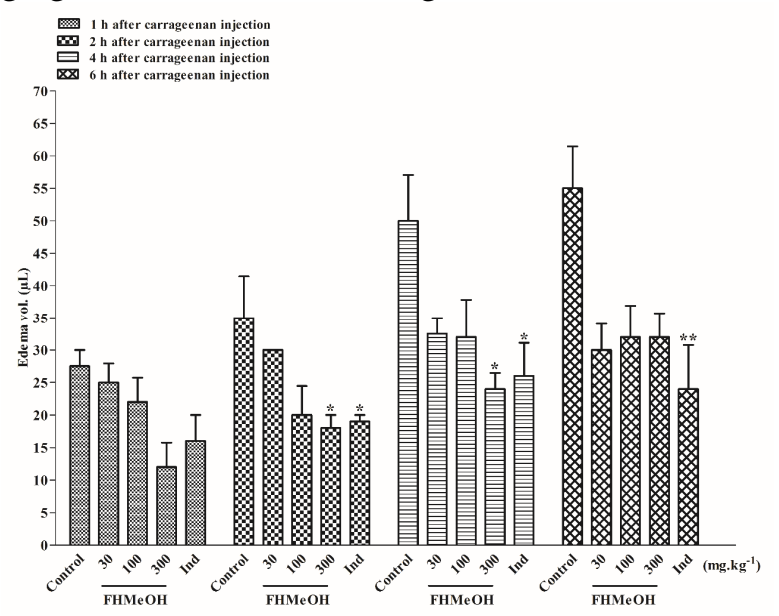

Figure 3. The effect of p.o. administration of the $\mathrm{FHMeOH}$ from $A$. nutans on carrageenan-induced paw edema in mice. Data were analyzed by ANOVA followed by Bonferroni's multiple comparison post-hoc test. Values are expressed as the mean \pm SEM $(\mathrm{n}=6) .{ }^{*} p<0.05$ and ${ }^{* *} p<0.01$ compared with the control group.

In contrast, i.p. treatment with $\mathrm{FHMeOH}$ at minor doses (50 and $100 \mathrm{mg} \cdot \mathrm{kg}^{-1}$ ) exerted longlasting anti-inflammatory effects that remained significant $6 \mathrm{~h}$ after inflammatory stimulus (Figure
4). The inhibitory values of paw edema at 2 and $4 \mathrm{~h}$ post-carrageenan-induced acute inflammation were $95.45 \%(p<0.001)$ and $74.29 \%(p<0.001)$, respectively, for $50 \mathrm{mg} \cdot \mathrm{kg}^{-1}$ of the $\mathrm{FHMeOH}$. 


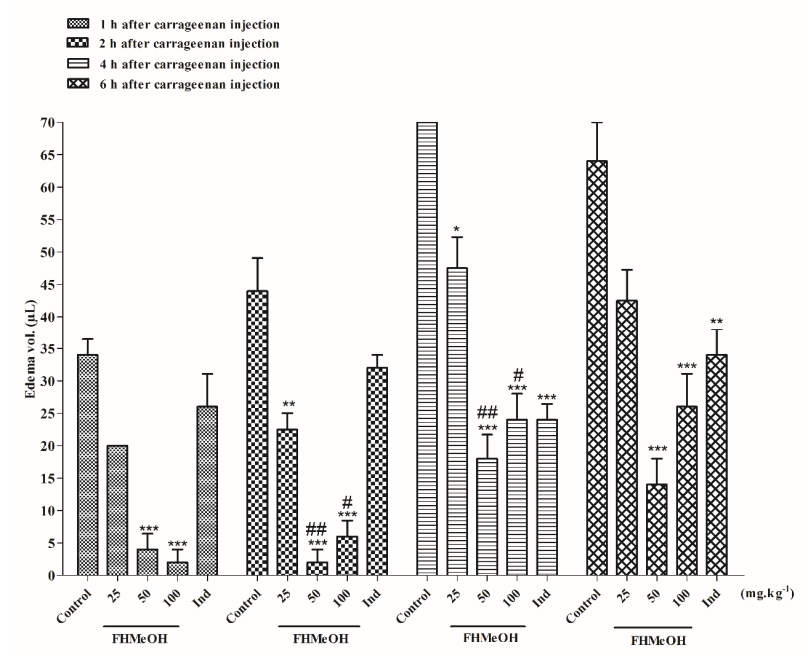

Figure 4. The effect of i.p. administration of the hydromethanolic fraction (FHMeOH) from A. nutans on carrageenan-induced paw edema. Data were analyzed by ANOVA followed by Bonferroni's multiple comparison post-hoc test. Values are expressed as the mean $\pm \operatorname{SEM}(\mathrm{n}=6) .{ }^{*} p<0.05,{ }^{* *} p<$ 0.01 and $^{* * * *} p<0.001$ as compared with the control; ${ }^{\#} p<0.05$ and ${ }^{\# \#} p<0.01$ as compared with the 25 mg.kg ${ }^{-1} \mathrm{FHMeOH}$ group.

\section{Antinociceptive activity of the FHMeOH}

FHMeOH at doses of 50 and 100 mg.kg-1 (i.p.) induced a significant increase in the latency of reaction, and the central antinociceptive effects began 90 min post both treatments and were still observable after $120 \mathrm{~min}$ for the $50 \mathrm{mg} \cdot \mathrm{kg}^{-1}$ (Figure $5)$.

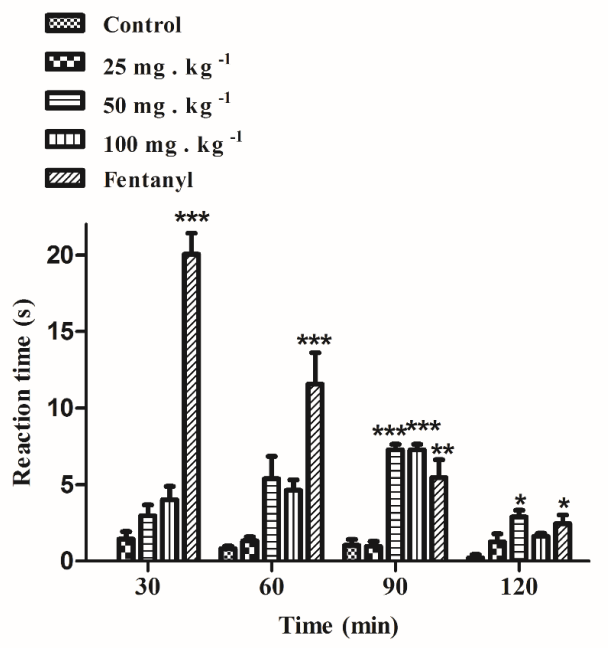

Figure 5. Effects of i.p. administration of the hydromethanolic fraction (FHMeOH) in the hot-plate model. Data were analyzed by ANOVA followed by Bonferroni's multiple comparison post-hoc test. Values are expressed as the mean $\pm \operatorname{SEM}(\mathrm{n}=7) .{ }^{*} p<0.05,{ }^{* *} p<0.01$ and ${ }^{* * *} p<0.001$ as compared with the control.

\section{DISCUSSION}

The UFLC analysis in FHMeOH of $A$. nutans leaves revealed that quercetin-3-Ogalactopyranoside is the identified phenolic compound which is the major constituent. The quantification by the UFLC-DAD method was validated and showed linearity, selectivity, and precision (BRASIL, 2003; DE AMORIM et al.,
2014; LANDIM; FEITOZA; DA COSTA, 2013). From the Annonaceae family, reports including the quantitative determination of metabolites are uncommon, in particular for flavonoids (GARCÍASALAS et al., 2015), and most of the studies in the literature have evaluated the alkaloid and acetogenin content, because these two classes are the main ones in the species of the family (ALMEIDA, J. R. G. S.; JUNIOR, R. G. O; DE OLIVEIRA, 2015). 
Currently, studies involving polyphenols such as flavonoids and chlorogenic acid derivatives have also gained great importance due to their diverse biological properties such as antioxidant, anti-inflammatory, antinociceptive, antimicrobial, and cardioprotective activity, among others (CALDERÓN-MONTAÑO et al., 2011; GALVÃO, STANLEY DE S. L. MONTEIRO et al., 2016; GARCÍA-LAFUENTE et al., 2009; GEORGIEV; ANANGA; TSOLOVA, 2014).

A direct relationship among antioxidant activity, phenolic compounds, and antiinflammatory efficacy has been demonstrated in the literature (FORMAGIO et al., 2013a, 2013b; HIRANO et al., 2001), including in certain Annona species. The methanolic extract from A. crassiflora, for instance, has been shown to have a high total phenolic and flavonoid content (BENITES et al., 2015), and it effectively reduced paw edema and leukocyte recruitment induced by carrageenan at doses of 100 and $300 \mathrm{mg} \cdot \mathrm{kg}^{-1}$ (ROCHA et al., 2016). Similarly, the methanolic extract of $A$. dioica has high levels of total phenols and flavonoids, and in the concentration of 30 to $300 \mathrm{mg} \cdot \mathrm{kg}^{-1}$ p.o., it exhibited an anti-edematogenic effect in carrageenan-induced paw edema in a time- and dose-dependent manner (FORMAGIO et al., 2013b). A. reticulata has been also shown to possess strong antioxidant ability and dose-dependent inhibition of paw edema following carrageenan injection in rats (KANDIMALLA et al., 2016).

The present study demonstrated, for the first time, the antioxidant, anti-inflammatory and antinociceptive activities of the $\mathrm{FHMeOH}$ of $A$. nutans leaves. Moreover, the anti-inflammatory and antinociceptive activities of $\mathrm{FHMeOH}$ were demonstrated using acute inflammation and thermal hyperalgesia models in mice. Carrageenan injection into the paw provokes a biphasic response characterized by the initial phase (0 to $1 \mathrm{~h}$ ) and the later phase (over $1 \mathrm{~h}$ ). In the first phase, the release of histamine, serotonin, and bradykinins, and, to a lesser extent, prostaglandins occurs. The later phase is related to the overproduction of prostaglandins and polymorphonuclear leukocyte migration (CUZZOCREA et al., 1998). The p.o. treatment with $\mathrm{FHMeOH}$ failed to significantly inhibit paw edema formation with the lowest doses tested (30 and $\left.100 \mathrm{mg} \cdot \mathrm{kg}^{-1}\right)$. Only the highest dose of 300 $\mathrm{mg} / \mathrm{kg} \mathrm{FHMeOH}$ significantly inhibited paw edema 2 and $4 \mathrm{~h}$ after carrageenan injection. Since this inhibition was no longer observed at $t=6 \mathrm{~h}$, this experiment suggests a low bioavailability by this route. On the other hand, the $\mathrm{FHMeOH}$ administered via i.p. exhibited significant anti- edematogenic activity in both phases. According to the literature, in the some studies of the pharmacological effects of natural products, using these models and the intraperitoneal route, the treatments with plant extracts showed antiinflammatory and antinociceptive activities at higher doses (75-500 mg. $\mathrm{kg}^{-1}$ ) (ALMEIDA et al., 2012; IBRAHIM et al., 2002; NARDI et al., 2003; SADANHA et al., 2016) than those used for FHMeOH in the present study.

Regarding the antioxidant activity, the DPPH radical-scavenging potential was used and is often compared with that of butylated hydroxytoluene (BHT), a commercial antioxidant used as a food additive (BURDA et al., 2001). As for measured by DPPH radical scavenging, FHMeOH presented an $\mathrm{IC}_{50}$ of $4.89 \mu \mathrm{g} . \mathrm{mL}-1$, which was superior to that shown by BHT $\left(\mathrm{IC}_{50}=16.36\right.$ $\left.\mu \mathrm{g} \cdot \mathrm{mL}^{-1}\right)$. The $\mathrm{IC}_{50}$ of $A$. nutans is lower than the methanolic extract $\left(17.84 \mu \mathrm{g} \cdot \mathrm{mL}^{-1}\right)$ of A. dioica leaves (FORMAGIO et al., 2013b), and A. dioica presented high rates of flavonoids (FORMAGIO et al., 2013b). Although flavonoids present known antioxidant activity, it seems that the diverse metabolic profile of $A$. nutans has better antioxidant activity than other Annona species with higher content in flavonoids. A possible cause for these data is the presence of other metabolites which presented an antioxidant action such as proaporphine alkaloids stepharine (AVULA et al., 2018; COSTA et al., 2015), aporphine magnoflorine (KUKULA-KOCH et al., 2016; NASEER et al., 2015), and oxoaporphine xylopine (COSTA et al., 2010).

As soon as we identified the antiinflammatory activity of $\mathrm{FHMeOH}$, we tested its analgesic activity, because these properties are shared by several non-steroidal anti-inflammatory drugs. The hot-plate model is a specific central antinociceptive assay, and the nociceptive response to thermal stimulus is supraspinally integrated (JULIUS, D; BASBAUM, 2001; WOOLFE; MACDNOALD, 1944). The FHMeOH produced central antinociceptive effects, verified by the increase in reaction time. However, further studies are needed to establish the possible mechanisms of the antinociceptive action of $\mathrm{FHMeOH}$ (SALDANHA et al., 2016).

It can be stated that inflammation and nociception are correlated, because nociception is one of the cardinal signs of inflammation (LENARDAO et al., 2016; YIMAM et al., 2016). It is also known that flavonoids and cinnamic derivatives, for example, chlorogenic acids, have anti-inflammatory and antinociceptive activities 
(GARCÍA-LAFUENTE et al., 2009; GEORGIADES et al., 2014; RATHEE et al., 2009; SERAFINI; PELUSO; RAGUZZINI, 2010; ZHAO, 2015; ZHU et al., 2013). These secondary metabolites may act via the inhibition of prostaglandin synthesis, neutrophil degranulation, and histamine, phosphodiesterase and protein kinases release (BASTOS, D. H. M.; ROGERO, M. M.; AREAS, 2009; RATHEE et al., 2009). The flavonoids and cinnamic derivatives play an important role because they present several biological actions besides anti-inflammatory and antinociceptive activities, such as antioxidant and anti-microbial effects, as well as the modulation of metabolic disorders (NAVEED et al., 2018). The antinociceptive and anti-inflammatory activities of $\mathrm{FHMeOH}$ can be attributed, at least in part, to the metabolites found in the fractions, such as flavonoids and chlorogenic acid derivatives.

\section{CONCLUSION}

The present study demonstrates, for the first time, that the $\mathrm{FHMeOH}$ fraction obtained from the leaves of $A$. nutans possesses in vivo antiinflammatory and antinociceptive activities. Furthermore, the combination of phenolics present in this fraction can explain, at least partially, the effects observed. These activities raise interest in the therapeutic potential of the $\mathrm{FHMeOH}$ for the treatment and/or management of inflammatory and painful conditions.

\section{ACKNOWLEDGEMENTS AND FUNDING}

This work was supported by the Coordenação de Aperfeiçoamento de Pessoal do Nivel Superior (CAPES) in the CAPES/PNPD program, under the number 2833-2011. The authors acknowledge FAPEMIG and Federal University of São João del-Rei postgraduate fellowship and CNPq for an awarded research grant.

RESUMO: Annona nutans (Annonaceae) é uma espécie de planta encontrada na Bolívia, Paraguai, Argentina e no Cerrado brasileiro, especificamente nos estados de Mato Grosso e Mato Grosso do Sul (Brasil). Seus nomes mais comuns são aratico e Araticû-Mi e Araticĥ- $\tilde{N} u$. As contribuições da pesquisa em relação à composição química e atividades biológicas dos extratos de $A$. nutans são raras, com apenas quatro artigos encontrados na literatura. Portanto, o presente estudo avaliou as atividades anti-inflamatória e antinociceptiva da fração hidrometanólica $(\mathrm{FHMeOH})$ utilizando edema de pata induzido por carragenina e testes de placa quente. Além disso, a atividade antioxidante foi avaliada por meio de sequestro de radical DPPH, e foram realizados ensaios de quantificação de fenóis, flavonoides e taninos totais e quantificação dos principais metabólitos por CL-EM. O tratamento oral com a FHMeOH (na dose de $300 \mathrm{mg} \cdot \mathrm{kg}^{-1}$ ) reduziu significativamente o edema da pata 2 e $4 \mathrm{~h}$ após o estímulo inflamatório. Por outro lado, o tratamento intraperitoneal (i.p.) com FHMeOH (50 e $\left.100 \mathrm{mg} \cdot \mathrm{kg}^{-1}\right)$ provou ser mais eficaz e a inibição da inflamação aguda foi ainda visível 6 horas após a injeção de carragenina. Nas doses de 50 e 100 mg.kg-1 (i.p.), FHMeOH exibiu efeitos antinociceptivos centrais aumentando a latência da reação no modelo de placa quente. $\mathrm{FHMeOH}$ apresentou potencial antioxidante e os metabólitos quercetina-3- $O$-galactosídeo, quercetina-3- $O$-glicosídeo, isoramnetina-3-O-galactosídeo, quercetina- 3-O- $\beta$ - $D$-apiofuranosil-(1 $\rightarrow 2)$-galactopiranosídeo e ácido clorogênico foram identificados e quantificados por CL-EM. Nossos resultados indicam, pela primeira vez, que o FHMeOH possui efeitos anti-inflamatórios, antinociceptivos e antioxidantes, sendo uma fonte promissora de estudos para novos medicamentos fitoterápicos.

PALAVRAS-CHAVE: Annona nutans. Flavonóides. Anti-inflamatório. DPPH. Antinociceptiva. Quantificação por CLAE

\section{REFERENCES}

ALMEIDA, J. R. G. DA S.; ARAÚJO, E. C. DA C.; RIBEIRO, L. A. DE A.; LIMA, J. T. DE; NUNES, X. P.; CARNEIRO LÚCIO, A. S. S.; AGRA, M. DE F.; BARBOSA FILHO, J. M. Antinociceptive Activity of Ethanol Extract from Duguetia chrysocarpa Maas (Annonaceae). The Scientific World Journal, v. 2012, p. 1-6, 2012. https://doi.org/10.1100/2012/859210 
ALMEIDA, J. R. G. S.; JUNIOR, R. G. O; DE OLIVEIRA, A. P. Annonaceae: Tópicos Selecionados. 1. ed. Curitiba: CRV, 2015.

AMORIM, M. R. DE; RINALDO, D.; AMARAL, F. P. DO; VILEGAS, W.; MAGENTA, M. A. G.; VIEIRA, G. M.; SANTOS, L. C. DOS. HPLC-DAD based method for the quantification of flavonoids in the hydroethanolic extract of Tonina fluviatilis Aubl. (Eriocaulaceae) and their radical scavenging activity. Quimica Nova, v. 37, n. 7, p. 1122-1127, 2014.

AVULA, B.; BAE, J. Y.; MAJRASHI, T.; WU, T. Y.; WANG, Y. H.; WANG, M.; ALI, Z.; WU, Y. C.; KHAN, I. A. Targeted and non-targeted analysis of annonaceous alkaloids and acetogenins from Asimina and Annona species using UHPLC-QToF-MS. Journal of Pharmaceutical and Biomedical Analysis, v. 159, p. 548-566, 2018. https://doi.org/10.1016/j.jpba.2018.07.030

BANOV, D.; BABY, R.; DEL, M.; KANEKO, T. M.; VAL, M.; VELASCO, R. Caracteriza çã o do Extrato Seco de Ginkgo biloba L . em Formula çõ es de Uso T ó pico. v. 25, n. 2, p. 219-224, 2006.

BASTOS, D. H. M.; ROGERO, M. M.; AREAS, J. A. G. dos alimentos no contexto de processos inflamatórios relacionados à obesidade. Arquivos Brasileiros de Endocrinologia \& Metabologia, v. 53, n. 5, p. 646-656, 2009. https://doi.org/10.1590/S0004-27302009000500017

BENITES, R.; FORMAGIO, A.; ARGANDONA, E.; VOLOBUFF, C.; TREVIZAN, L.; VIEIRA, M.; SILVA, M. Contents of constituents and antioxidant activity of seed and pulp extracts of Annona coriacea and Annona sylvatica. Brazilian Journal of Biology, v. 75, n. 3, p. 685-691, 2015. https://doi.org/10.1590/15196984.21313

BERMEJO, A. ET AL. View Article Online / Journal Homepage / Table of Contents for this issue REVIEW Acetogenins from Annonaceae: recent progress in isolation, synthesis and mechanisms of action. Natural Product Research, v. 22, p. 269-303, 2005.

BRASIL, A. N. D. V. S. Resolução - RE no 899 - "Guia para validação de métodos analíticos e bioanalíticos". Ministério da Saúde, p. 1-15, 2003.

. Farmacopeia Brasileira. Farmacopeia Brasileira, 5a edição, v. 2, p. 904p, 2010a.

. Farmacopeia Brasileira. Farmacopeia Brasileira, 5a edição, v. 1, p. 1-523, 2010 b.

BRITO, W. A. DE B. Desenvolvimento e validação de métodos analíticos para determinação de diferentes guanilhidrazonas. [s.l.] Universidade Federal do Rio Grande do Norte, 2014.

BURDA, S.; BURDA, S.; OLESZEK, W.; OLESZEK, W. Antioxidant and Antiradical Activities of Flavonoids. Journal of Agricultural and Food Chemistry, v. 49, n. JULY 2001, p. 2774-2779, 2001. https://doi.org/10.1021/jf001413m

CALDERÓN-MONTAÑO, J.; BURGOS-MORÓN, E.; PÉREZ-GUERRERO, C.; LÓPEZ-LÁZARO, M. A review on the dietary flavonoid kaempferol. Mini reviews in medicinal chemistry, v. 11, n. 4, p. 298-344, 2011. https://doi.org/10.2174/138955711795305335

CAPARROS-LEFEBVRE, D.; STEELE, J. Atypical parkinsonism on Guadeloupe, comparison with the parkinsonism-dementia complex of Guam, and environmental toxic hypotheses. Environmental Toxicology and Pharmacology, v. 19, n. 3, p. 407-413, 2005. https://doi.org/10.1016/j.etap.2004.12.052

CAVÉ, A.; CHABOCHE, C.; FIGADÈRE, B.; HARMANGE, J. C.; LAURENS, A.; PEYRAT, J. F.; PICHON, M.; SZLOSEK, M.; COTTE-LAFITTE, J.; QUÉRO, A. M. Study of the structure-activity relationships of the acetogenin of annonaceae, muricatacin and analogues. European Journal of Medicinal Chemistry, v. 32, n. 7-8, p. 617-623, 1997. https://doi.org/10.1016/S0223-5234(97)83287-4 
CHATROU, L. W.; PIRIE, M. D.; ERKENS, R. H. J.; COUVREUR, T. L. P.; NEUBIG, K. M.; ABBOTT, J. R.; MOLS, J. B.; MAAS, J. W.; SAUNDERS, R. M. K.; CHASE, M. W. A new subfamilial and tribal classification of the pantropical flowering plant family Annonaceae informed by molecular phylogenetics. Botanical Journal of the Linnean Society, v. 169, n. 1, p. 5-40, 2012. https://doi.org/10.1111/j.10958339.2012.01235.x

CLIFFORD, M. N.; JOHNSTON, K. L.; KNIGHT, S.; KUHNERT, N. Hierarchical scheme for LC-MS ${ }^{\mathrm{n}}$ identification of chlorogenic acids. Journal of Agricultural and Food Chemistry, v. 51, n. 10, p. 2900-2911, 2003. https://doi.org/10.1021/jf026187q

CORRÊA, M. P. Diccionario das Plantas Uteis do Brasil e das Exoticas Cultivadas. V.I ed. Rio de Janeiro: Vol I, Ministério da Agricultura, Ed. Imprensa Nacional, 1926.

COSTA, E. V.; PINHEIRO, M. L. B.; BARISON, A.; CAMPOS, F. R.; SALVADOR, M. J.; MAIA, B. H. L. N. S.; CABRAL, E. C.; EBERLIN, M. N. Alkaloids from the bark of Guatteria hispida and their evaluation as antioxidant and antimicrobial agents. Journal of Natural Products, v. 73, n. 6, p. 1180-1183, 2010. https://doi.org/10.1021/np100013r

COSTA, E. V.; SAMPAIO, M. F. C.; SALVADOR, M. J.; NEPEL, A.; BARISON, A. Chemical constituents from the stem bark of Annona pickelii (Annonaceae). Quimica Nova, v. 38, n. 6, p. 769-776, 2015. https://doi.org/10.5935/0100-4042.20150069

COUVREUR, T. L. P.; PIRIE, M. D.; CHATROU, L. W.; SAUNDERS, R. M. K.; SU, Y. C. F.; RICHARDSON, J. E.; ERKENS, R. H. J. Early evolutionary history of the flowering plant family Annonaceae: Steady diversification and boreotropical geodispersal. Journal of Biogeography, v. 38, n. 4, p. 664-680, 2011. https://doi.org/10.1111/j.1365-2699.2010.02434.x

CUZZOCREA, S.; ZINGARELLI, B.; HAKE, P.; SALZMAN, A. L.; SZABO, C. Antiinflammatory effects of mercaptoethylguanidine, a combined inhibitor of nitric oxide synthase and peroxynitrite scavenger, in carrageenan-induced models of inflammation. Free Radical Biology and Medicine, v. 24, n. 3, p. 450-459, 1998. https://doi.org/10.1016/S0891-5849(97)00280-3

FERRAZ, C. R.; SILVA, D. B.; PRADO, L. C. DA S.; CANABRAVA, H. A. N.; BISPO-DA-SILVA, L. B. Antidiarrhoeic effect and dereplication of the aqueous extract of Annona crassiflora (Annonaceae). Natural Product Research, v. 6419, n. November, p. 1-5, 2017. https://doi.org/10.1080/14786419.2017.1396589

FINNEY, D. J. Probit analysis, a statical treatment of the sigmoid response curve., 1980.

FORMAGIO, A. S. N.; KASSUYA, C. A. L.; NETO, F. F.; VOLOBUFF, C. R. F.; IRIGUCHI, E. K. K.; VIEIRA, M. DO C.; FOGLIO, M. A. The flavonoid content and antiproliferative, hypoglycaemic, antiinflammatory and free radical scavenging activities of Annona dioica St. Hill. BMC complementary and alternative medicine, v. 13, n. 1, p. 14, 2013. https://doi.org/10.1186/1472-6882-13-14

FORMAGIO, A. S. N.; VIEIRA, M. DO C.; SANTOS, L. A. C. DOS; CARDOSO, C. A. L.; FOGLIO, M. A.; CARVALHO, J. E. DE; ANDRADE-SILVA, M.; KASSUYA, C. A. L. Composition and Evaluation of the Anti-Inflammatory and Anticancer Activities of the Essential Oil from Annona sylvatica A. St.-Hil. Journal of Medicinal Food, v. 16, n. 1, p. 20-25, 2013. https://doi.org/10.1089/jmf.2011.0303

GALVÃO, STANLEY DE S. L. MONTEIRO, A. DE S.; SIQUEIRA, E. P.; BOMFIM, M. R. Q.; DIASSOUZA, M. V.; FERREIRA, G. F.; DENADAI, A. M. L.; SANTOS, ÁQUILA R. C.; SANTOS, V. L. DOS; SOUZA-FAGUNDES, E. M. DE; FERNANDES, E. S.; MONTEIRO-NETO, V. Annona glabra flavonoids act as antimicrobials by binding to Pseudomonas aeruginosa cell walls. Frontiers in Microbiology, v. 7, n. DEC, p. 1-9, 2016. https://doi.org/10.3389/fmicb.2016.02053 
GARCÍA-LAFUENTE, A.; GUILLAMÓN, E.; VILlARES, A.; ROSTAGNO, M. A.; MARTÍNEZ, J. A. Flavonoids as anti-inflammatory agents: Implications in cancer and cardiovascular disease. Inflammation Research, v. 58, n. 9, p. 537-552, 2009. https://doi.org/10.1007/s00011-009-0037-3

GARCÍA-SALAS, P.; GÓMEZ-CARAVACA, A. M.; MORALES-SOTO, A.; SEGURA-CARRETERO, A.; FERNÁNDEZ-GUTIÉRREZ, A. Identification and quantification of phenolic and other polar compounds in the edible part of Annona cherimola and its by-products by HPLC-DAD-ESI-QTOF-MS. Food Research International, v. 78, p. 246-257, 2015. https://doi.org/10.1016/j.foodres.2015.10.002

GEORGIADES, P.; PUDNEY, P. D. A.; ROGERS, S.; THORNTON, D. J.; WAIGH, T. A. Tea derived galloylated polyphenols cross-link purified gastrointestinal mucins. PLoS ONE, v. 9, n. 8, 2014. https://doi.org/10.1371/journal.pone.0105302

GEORGIEV, V.; ANANGA, A.; TSOLOVA, V. Recent advances and uses of grape flavonoids as nutraceuticals. Nutrients, v. 6, n. 1, p. 391-415, 2014. https://doi.org/10.3390/nu6010391

GLEYE, C. et al. MURICADIENIN, MURIDIENINS AND CHATENAYTRIENINS, THE EARLY PRECURSORS OF ANNONACEOUS ACETOGENINS*. Phytochemistry, v. 4, n. 5, p. 749-754, 1998. https://doi.org/10.1016/S0031-9422(97)00908-4

GLEYE, C.; RAYNAUD, S.; FOURNEAU, C.; LAURENS, A.; LAPRÉVOTE, O.; SERANI, L.; FOURNET, A.; HOCQUEMILLER, R. Cohibins $\mathrm{C}$ and $\mathrm{D}$, two important metabolites in the biogenesis of acetogenins from Annona muricata and Annona nutans. Journal of Natural Products, v. 63, n. 9, p. 1192-1196, 2000. https://doi.org/10.1021/np000061a

GONÇALVES, C. A. et al. Evaluation of mutagenic, teratogenic, and immunomodulatory effects of Annona nutans hydromethanolic fraction on pregnant mice. Genetics and Molecular Research, v. 13, n. 2, p. 43924405, 2014. https://doi.org/10.4238/2014.June.11.3

GREEN, C. E.; HIBBERT, S. L.; WILLIAMS, L. A. D.; BAILEY-SHAW, Y. A.; SALMON, C.; SMITH, A. 2 . Evaluation of the total phenols, total flavonoids, total tannins, and antioxidant capacity of the young vs . mature Annona muricata ( sour sop) tea leaf grown in Jamaica. v. 661, n. 2, 2015.

HIRANO, R.; SASAMOTO, W.; MATSUMOTO, A.; ITAKURA, H.; IGARASHI, O.; KONDO, K. Antioxidant Ability of Various Flavonoids against DPPH Radicals and LDL Oxidation. J Nutr Sci Vitaminol, v. 47, p. 357-362, 2001. https://doi.org/10.3177/jnsv.47.357

IBRAHIM, T.; MARCOS, J.; CUNHA, T.; MADI, K.; LEA, M. B.; COSTA, S. S.; GONC, V. L. Immunomodulatory and anti-inflammatory effects of Kalanchoe brasiliensis. v. 2, p. 875-883, 2002. https://doi.org/10.1016/S1567-5769(02)00020-6

JULIUS, D; BASBAUM, A. I. Molecular mechanisms of nociception. Nature, v. 413, n. September, p. 203210, 2001. https://doi.org/10.1038/35093019

KANDIMALLA, R.; DASH, S.; KALITA, S.; CHOUDHURY, B.; MALAMPATI, S.; KALITA, K.; KOTOKY, J. Bioactive guided fractions of Annona reticulata L. bark: Protection against liver toxicity and inflammation through inhibiting oxidative stress and proinflammatory cytokines. Frontiers in Pharmacology, v. 7, n. JUN, p. 1-12, 2016. https://doi.org/10.3389/fphar.2016.00168

KUKULA-KOCH, W.; KOCH, W.; ANGELIS, A.; HALABALAKI, M.; ALIGIANNIS, N. Application of pHzone refining hydrostatic countercurrent chromatography (hCCC) for the recovery of antioxidant phenolics and the isolation of alkaloids from Siberian barberry herb. Food Chemistry, v. 203, p. 394-401, 2016.

https://doi.org/10.1016/j.foodchem.2016.02.096 
LANDIM, L. P.; FEITOZA, G. S.; COSTA, J. G. M. DA. Development and validation of a HPLC method for the quantification of three flavonoids in a crude extract of Dimorphandra gardneriana. Revista Brasileira de Farmacognosia, v. 23, n. 1, p. 58-64, 2013. https://doi.org/10.1590/S0102-695X2012005000111

LEBOEUF, M.; CAVE, A.; BHAUMIK, P. K.; MUKHERJEE, B.; MUKHERJEE, R. The phytochemistry of the annonaceae. Phytochemistry, v. 21, n. 12, p. 2783-2813, 1982. https://doi.org/10.1016/00319422(80)85046-1

LENARDAO, E. J.; SAVEGNAGO, L.; JACOB, R. G.; VICTORIA, F. N. Antinociceptive Effect of Essential Oils and Their Constituents: an Update Review. Journal of the Brazilian Chemical Society, v. 27, n. 3, p. 435-474, 2016. https://doi.org/10.5935/0103-5053.20150332

LEVY, L. Carrageenan paw edema in the mouse. Life Sciences, v. 8, n. 11, p. 601-606, 1969. https://doi.org/10.1016/0024-3205(69)90021-6

LIU, M.; HUANG, X.; LIU, Q.; CHEN, M.; LIAO, S.; ZHU, F.; SHI, S.; YANG, H.; CHEN, X. Rapid screening and identification of antioxidants in the leaves of Malus hupehensis using off-line two-dimensional HPLC-UV-MS/MS coupled with a 1,1'-diphenyl-2-picrylhydrazyl assay. Journal of Separation Science, v. 41, n. 12, p. 2536-2543, 2018. https://doi.org/10.1002/jssc.201800007

MORI, L. S.; BOLLER, S.; KASSUYA, C. A. L.; STEFANELLO, M. E. A.; ZAMPRONIO, A. R. Phytomedicine Analgesic effects of the ethanolic extract from Magnolia ovata (Magnoliaceae ) trunk bark and of N-acetylxylopine , a semi-synthetic analogue of xylopine. Phytomedicine, v. 18, p. 143-147, 2011. https://doi.org/10.1016/j.phymed.2010.06.001

MUHAMMAD, N.; SAEED, M.; H., K. Antipyretic, analgesic and anti-inflammatory activity of Viola betonicifolia whole plant. BMC complementary and alternative medicine, v. 12, p. 1-8, 2012. https://doi.org/10.1186/1472-6882-12-59

NARDI, G.; FELIPPI, R.; DALBO, S.; SIQUEIRA-JUNIOR, J.; ARRUDA, D. C.; DELLE MONACHE, F.; TIMBOLA, A. K.; PIZZOLATTI, M. G.; CKLESS, K.; RIBEIRO-DO-VALLE, R. M. Anti-inflammatory and antioxidant effects of Croton celtidifolius bark. Phytomedicine, v. 10, p. 176-184, 2003.

https://doi.org/10.1078/094471103321659906

NASEER, S.; LONE, S. H.; LONE, J. A.; KHUROO, M. A.; BHAT, K. A. LC-MS guided isolation, quantification and antioxidant evaluation of bioactive principles from Epimedium elatum. Journal of Chromatography B: Analytical Technologies in the Biomedical and Life Sciences, v. 989, n. 1553, p. $62-$ 70, 2015. https://doi.org/10.1016/j.jchromb.2015.02.046

NAVEED, M. et al. Chlorogenic acid (CGA): A pharmacological review and call for further research. Biomedicine and Pharmacotherapy, v. 97, n. August 2017, p. 67-74, 2018. https://doi.org/10.1016/j.biopha.2017.10.064

RATHEE, P.; CHAUDHARY, H.; RATHEE, S.; RATHEE, D.; KUMAR, V.; KOHLI, K. Mechanism of Action of Flavonoids as Anti-inflammatory Agents: A Review. Inflammation \& Allergy - Drug Targets, v. 8, n. 3, p. 229-235, 2009. https://doi.org/10.2174/187152809788681029

RIBANI, M.; GRESPAN BOTTOLI, C. B.; COLLINS, C. H.; FONTES JARDIM, I. C. S.; COSTA MELO, L. F. Validação em métodos cromatográficos e eletroforéticos. Quimica Nova, v. 27, n. 5, p. 771-780, 2004. https://doi.org/10.1590/S0100-40422004000500017 
ROCHA, R. S.; KASSUYA, C. A. L.; FORMAGIO, A. S. N.; MAURO, M. D. O.; ANDRADE-SILVA, M.; MONREAL, A. C. D.; CUNHA-LAURA, A. L.; VIEIRA, M. D. C.; OLIVEIRA, R. J. Analysis of the antiinflammatory and chemopreventive potential and description of the antimutagenic mode of action of the Annona crassiflora methanolic extract. Pharmaceutical Biology, v. 54, n. 1, p. 35-47, 2016. https://doi.org/10.3109/13880209.2015.1014567

SADANHA, A. A. et al. Chemical composition and anti-inflammatory activity of the leaves of Byrsonima verbascifolia. Journal natural medicine, 2016.

SALDANHA, A. A.; SIQUEIRA, J. M.; CASTRO, A. H. F.; MATOS, N. A.; KLEIN, A.; SILVA, D. B.; CAROLLO, C. A.; SOARES, A. C. Peripheral and central antinociceptive effects of the butanolic fraction of Byrsonima verbascifolia leaves on nociception-induced models in mice. Inflammopharmacology, 2016. https://doi.org/10.1007/s10787-016-0300-5

SERAFINI, M.; PELUSO, I.; RAGUZZINI, A. Flavonoids as anti-inflammatory agents. Proceedings of the Nutrition Society, v. 69, n. 03, p. 273-278, 2010. https://doi.org/10.1017/S002966511000162X

SHANGGUAN, Y.; HE, J.; KANG, Y.; WANG, Y.; YANG, P.; GUO, J.; HUANG, J. Structural Characterisation of Alkaloids in Leaves and Roots of Stephania kwangsiensis by LC-QTOF-MS. Phytochemical Analysis, v. 29, n. 1, p. 101-111, 2018. https://doi.org/10.1002/pca.2718

SILVA, N. L. Estudo fitoquímico das folhas de Annona nutans ( R . E . Fries ). [s.l.] Universidade Federal de São João Del-Rei, 2013.

SILVA, N. L. .; ZOBIOLE, N. N. .; SILVA, D. B. .; SARTORI, A. L. . B. .; OLIVEIRA, J. .; PINTO, M. E. A. .; SANTOS, F. J. L. . DOS; SIQUEIRA, J. M. DE. CONSTITUINTES QUÍMICOS E ATIVIDADE FITOTÓXICA DAS FOLHAS DE Annona nutans. v. 38, n. 3, p. 370-377, 2015.

TITOVA, M. V; RESHETNYAK, O. V; OSIPOVA, E. A.; SHUMILO, N. A.; ORESHNIKOV, A. V; NOSOV, A. M. Submerged Cultivation of Stephania glabra ( Roxb .) Miers Cells in Different Systems : Specific Features of Growth and Accumulation of Alkaloid Stepharine. Applied Biochemistry and Microbiology, v. 48, n. 7, p. 645-649, 2012. https://doi.org/10.1134/S0003683812070046

Tropicos.org. Disponível em: <www.tropicos.org>. Acesso em: 1 ago. 2017.

VERZA, S. G.; KREINECKER, M. T.; REIS, V.; HENRIQUES, A. T.; ORTEGA, G. G. Avaliação das variáveis analíticas do método de folin-ciocalteu para determinação do teor de taninos totais utilizando como modelo o extrato aquoso de folhas de Psidium guajava L. Quimica Nova, v. 30, n. 4, p. 815-820, 2007. https://doi.org/10.1590/S0100-40422007000400011

WOOLFE, G.; MACDNOALD, A. D. The evaluation of the analgesic action of pethidine hydrochloride (demerol). The Journal of Pharmacology and Experimental Therapeutics, v. 80, n. 3, p. 300-307, 1944.

YIMAM, M.; LEE, Y.-C.; JIAO, P.; HONG, M.; NAM, J.-B.; BROWNELL, L.; HYUN, E.; JIA, Q. UP1306, a botanical composition with analgesic and anti-inflammatory effect. Pharmacognosy Research, v. 8, n. 3, p. 186, 2016. https://doi.org/10.4103/0974-8490.182918

ZHANG, Q.; ZHANG, J.; SHEN, J.; SILVA, A.; DENNIS, D. A.; BARROW, C. J. A simple 96-well microplate method for estimation of total polyphenol content in seaweeds. Journal of Applied Phycology, v. 18, n. 3-5, p. 445-450, 2006. https://doi.org/10.1007/s10811-006-9048-4

ZHAO, J. Flavonoid transport mechanisms: How to go, and with whom. Trends in Plant Science, v. 20, n. 9, p. 576-585, 2015. https://doi.org/10.1016/j.tplants.2015.06.007

ZHU, B.; ED, P.; KUMAR, S.; PANDEY, A. K. Flavonoids : Reviews Chemistry and Biological Activities of Flavonoids : An Overview. v. 2013, n. 3, p. 519-534, 2013. 